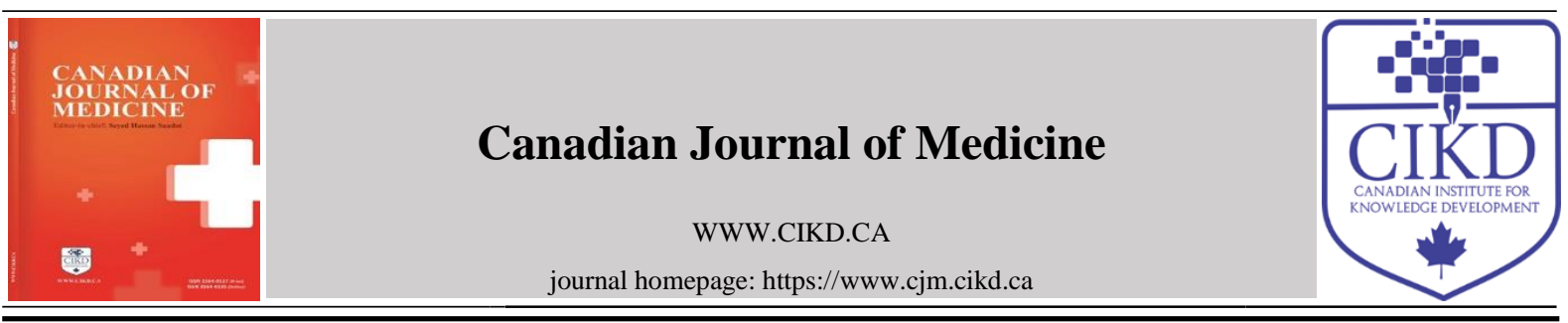

\title{
Presentation of Varicella-Zoster Virus Infection with Bladder Mass and Gross Hematuria
}

\author{
Mosa Asadi ${ }^{1 *}$, Mohammad Reza Fattahi ${ }^{2}$, Somayeh Mohammadi $^{3}$ \\ ${ }^{1,2}$ Nephrology and Urology Research Center, Baqiyatallah University of Medical Sciences, Tehran, \\ Iran \\ ${ }^{3}$ Department of Cardiovascular, Imam Khomeini Hospital Complex, Tehran University of Medical \\ Sciences, Tehran, Iran
}

\begin{tabular}{ll}
\hline & ABSTRACT \\
\cline { 2 - 2 } $\begin{array}{l}\text { Keywords: } \\
\text { Herpes Zoster; Hematuria, } \\
\text { Bladder mass }\end{array}$ & $\begin{array}{l}\text { Varicella-zoster virus reactivation can cause painful and vesicular rashes involving some } \\
\text { dermatomes, which is defined as herpes zoster. We reported a } 68 \text { years old man who had } \\
\text { come to the clinic with a complaint of hematuria. In the examination, varicella-zoster lesions } \\
\text { were visible on the left buttock. After beginning valacyclovir for the patient, cystoscopy was } \\
\text { done due to the existing polypoid mass in sonography. Red patches, fragile and bleeding } \\
25 \text { November } 2021\end{array}$ \\
$\begin{array}{l}\text { Received in revised form } \\
\text { places were seen in the cystoscopy on the left bladder wall without any evidence of any mass. } \\
\text { 14 December } 2021\end{array}$ & $\begin{array}{l}\text { This patient was managed conservatively. One week after the first ultrasonography, new } \\
\text { sonography by the same radiologist showed no evidence of bladder mass. }\end{array}$
\end{tabular}

Accepted

21 December 2021

*Correspondence:

asadi7723@gmail.com

CCIKD Publishing

\section{Background}

Herpes zoster is a blistering and painful rash caused by the reactivation of a varicella-zoster virus (VZV) involved in unilateral neural dermatomes. The most important risk factors for the incidence of herpes zoster are immunosuppression and aging. Some studies defined the incidence of herpes zoster as 3.4 cases per 1,000 persons per year in the United Kingdom [1]. The epidemiology of herpes zoster is affected by host factors that lead to the reactivation of the latent virus. The incidence of herpes zoster increases with advancing age. Most cases of herpes zoster occur in patients over 45 years of age. More than 10 cases per 1000 person-years are 
diagnosed in those younger than 75 years [2]. Herpes zoster is also more common in patients treated with immunosuppressive drugs, malignant diseases, human immunodeficiency virus infection, or organ transplants $[3,4,5,6,7]$.

\section{Case Report}

The patient was a 68 years old man who had come to the clinic with a complaint of hematuria. He exhibited painless gross hematuria. Sometimes small pieces of blood clot were excreted in the urine. He also had a burning sensation in his left buttock a week ago. The pain had diminished and was not noticeable at the visit. The clinical examination did not show any positive findings in the genitourinary system, but varicella-zoster lesions were visible on the left buttock. There was no history of cardiovascular disease using nonsteroidal anticoagulants and anti-inflammatory drugs. And also, her family had no history of urinary tract disease. $\mathrm{He}$ had a history of smoking and had quit smoking for 30 years. Complete laboratory tests were performed for liver and kidney functions, and urinalysis and urine culture were also done for the patient. The patient's hemoglobin $(\mathrm{Hb})$ was $16.3 \mathrm{~g} / \mathrm{dl}$, total leukocyte count was $5300 / \mathrm{mm}^{3}$. The urine analysis revealed many $\mathrm{RBC}, 3^{+}$positive drops of blood in the dipstick, and negative urine culture. The erythrocyte sedimentation rate (ESR), C-reaction protein (CRP), prothrombin time (PT), partial thromboplastin time (PTT), and serum creatinine were found to be in the normal range or has not changed significantly. In ultrasonography examination, the kidneys were normal in parenchymal, echogenicity and sizes, and also there were no stones and mass. In the bladder, one papillary mass was reported in the left anterolateral wall near the bladder neck $(17$ x $33 \mathrm{~mm})$. We nominated him for cystoscopy and transurethral resection of a bladder tumor (TUR-BT). Anesthesiologist and cardiovascular consultation were then requested. $\mathrm{He}$ was under treatment with valacyclovir, an antiviral medication, for four days during this period. It took almost a week from the first clinic visit until the cystoscopy. The patient had no burning pain in the buttocks and gross hematuria at cystoscopy. In cystoscopy, no urethral abnormalities and stricture disease were seen. There was an enlargement of the lateral lobes of the prostate with) $2 \mathrm{~cm}$ ) without a prominent middle lobe. The trabeculated bladder was slightly mild, and the left bladder wall had red patches, fragile and bleeding places without obvious papillary like urothelial cell carcinoma. This patient was managed conservatively. One week after the first ultrasonography, no evidence of bladder mass was detected by the same radiologist and. The diagnosis of varicella-zoster was based on the bladder mass on ultrasound and the disappearance of that bladder mass after one week of conservative treatment of concurrent varicella infection.

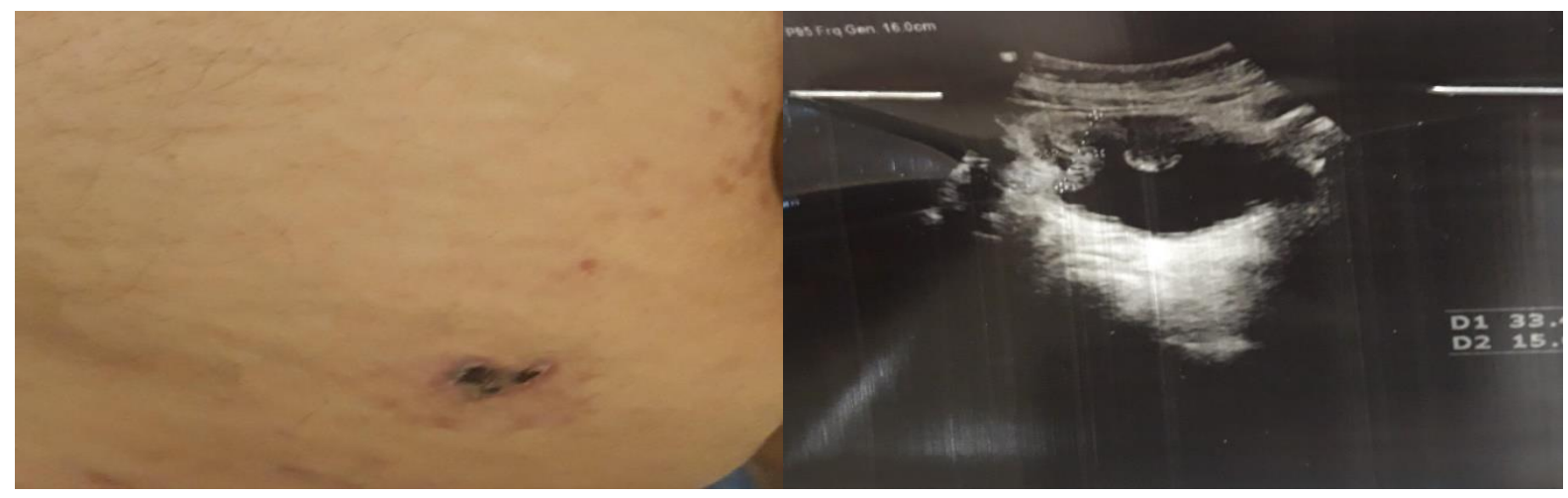

Varicella-zoster lesions on the left buttock

Papillary mass in sonography 


\section{Discussion}

Approximately $1 \%$ of the population experiences herpes zoster in their lifetime. In the United States, the annual incidence of herpes zoster has been estimated to be 2 cases per1000 patient years [8]. This rate increased to 9 cases per 1000 patient-years in patients over80 years old [9]. Herpes zoster may be more commonly diagnosed in immunocompromised patients [10]. Herpes zoster mostly affects the thoracolumbar (50-60\%) and facial dermatomes (10-20\%) [11], while the involvement of sacral dermatomes is uncommon. Only $5 \%$ of all cases of herpes zoster have sacral dermatomes involvement [12]. The most common complication of herpes zoster is neuralgia, which is more common in the elderly. Furthermore, $47 \%$ of patients over 60 years with herpes zoster have neuralgia [13]. Other complications include secondary bacterial infection, meningoencephalitis, transverse myelitis, cerebral vasculitis, pneumonitis, pancreatitis, myocarditis, hepatitis, contralateral hemiplegia, cranial nerve palsy, peripheral nerve palsy, disseminated infection in immunocompromised patients, and urinary retention [14]. Davidshah reported urinary retention as a complication of herpes zoster for the first time in 1890 [15]. The result of this paper showed that detrusor areflexia could cause urinary retention in such patients. In some studies, urogenital problems of herpes zoster infection have been reported $[16,17,18]$. Cystoscopy in patients with urogenital complications revealed intravesicular lesions with bladder wall inflammation [19]. According to some studies, acute retention of urine is more common in women than in men [20]. Hemorrhagic complications of varicella are more common in adults than children [21]. Petechiae, purpura, epistaxis, hematuria, and gastrointestinal hemorrhage during acute varicella are justified by thrombocytopenia. Thrombocytopenia may begin in the first week of the disease, although bleeding complications may last several weeks [22]. Involvement of the lumbosacral ganglion in herpes zoster may be capable of causing bladder dysfunctions or ileus [23]. Some studies have reported clinical involvement of the bladder in herpes zoster $[24,16]$. However, this study is the first clinical involvement of the bladder with a major manifestation of hematuria.

\section{References}

[1] Hope-Simpson, RE. The nature of herpes zoster: a long-term study and a new hypothesis. Proc R Soc Med. 1965;58:9-20.

[2] Schmader K, George L K, Burchett BM, Pieper CF, Hamilton JD. Racial differences in the occurrence of herpes zoster. J Infect Dis.1995;171:701-704.

[3] Cohen PR, Grossman ME. Clinical features of human immunodeficiency virus-associated disseminated herpes zoster virus infection-a review of the literature. Clin Exp Dermatol. 1989;14:273v276.

[4] Han CS, Miller W, Haake R, Weisdorf D. Varicella zoster infection after bone marrow transplantation: incidence, risk factors and complications. Bone Marrow Transplant. 1994;13:277v283.

[5] Locksley RM, Flournoy N, Sullivan KM, Myers JD. Infection with varicella-zoster virus after marrow transplantation. J Infect Dis. 1985;152:1172-1181.

[6] Schuchter LM, Wingard JR, Piantadosi S, Burns WH, Santos GW, Saral R. Herpes zoster infection after autologous bone marrow transplantation. Blood. 1989;74:1424-1427.

[7] Whitley RJ. Varicella-zoster virus infections. In: Galasso GJ, Whitley RJ, Merigan TC, eds. Antiviral Agents and Viral Diseases of Man. New York: Raven Press; 1990;235-263.

[8] Helgason S, Sigurdsson JA, Gudmundsson S. The clinical course of herpes zoster: a prospective study in primary care. Eur J Gen Pract. 1996 1;2(1):12-6.

[9] Insinga RP, Itzler RF, Pellissier JM, Saddier P, Nikas AA. The incidence of herpes zoster in a United States administrative database. J Gen Intern Med. 2005;20(8):748-53.

[10] Hope-Simpson, R. Edgar. The nature of herpes zoster: a long-term study and a new hypothesis. Proc R Soc Med. 1965;58(1): 9-20.

[11] Spray A, Glaser DA. Herpes zoster of the penis: an unusual location for a common eruption. Journal of the American Academy of Dermatology. 2002;47(2):S177-9.

[12] Oates JK, Greenhouse PR. Retention of urine in anogenital herpetic infection. Lancet. 1978;1(8066):691-692. 
[13] Kost RG, Straus SE. Postherpetic neuralgia — pathogenesis, treatment, and prevention. N Engl J Med. 1996;335(1):32-42.

[14] Odrcich M, Bailey JM, Cahill CM, Gilron I. Chronobiological characteristics of painful diabetic neuropathy and postherpetic neuralgia: diurnal pain variation and effects of analgesic therapy. Pain. 2006;120(1-2):207-212.

[15] Davidshah E.“Communication,” Berliner und M"unchener Tier"arztlicheWochenschrift.1890; 1,27:695.

[16] Gibon NK. A case of herpes zoster with involvement of the urinary bladder. Br J Urol. 1956;28(4):417-421.

[17] Broseta E, Osca JM, Morera J, Martinez-Agullo E, Jimenez-Cruz JF. Urological manifestations of herpes zoster. Eur Urol. 1993;24:244-7.

[18] Hiraga A, Nagumo K, Sakakibara R, Kojima S, Fujinawa N, Hashimoto T. Loss of urinary voiding sensation due to herpes zoster. Neurourology and Urodynamics: Official journal of the ICS 2003;22(4):335-7.

[19] Tsai HN, Wu WJ, Huang SP, et al. Herpes zoster induced neuropathic bladder--a case report. Kaohsiung J Med Sci. 2002;18(1):39-44.

[20] Dauleh MI, Byrne DJ. Unusual cause for acute retention of urine. J R Coll Surg Edinb. 1995;40(3):197.

[21] Preblud SR. Varicella: complications and costs. Pediatrics. 1986;78(4 Pt 2):728-735.

[22] Feusner JH, Slichter SJ, Harker LA. Mechanisms of thrombocytopenia in varicella. Am J Hematol. 1979;7(3):255-264. doi:10.1002/ajh.2830070308

[23] Reichman, R. C. Neurologic complications of varicella-zoster infections. Ann Intern Med. 1978;375:89-96.

[24] Blank H, Rake GW. Viral and rickettsial diseases of the skin, eye, and mucous membranes of man. Little, Brown; 1955.

\section{Acknowledgements}

Not applicable.

\section{Disclosure Statement}

No potential conflict of interest was reported by the authors.

\section{Funding Acknowledgements}

Not applicable. 